\title{
Pemberdayaan Masyarakat dan Komunitas dalam Program Desa Wisata Jogoboyo Purworejo
}

\author{
People and Community Empowerment \\ in the Jogoboyo Purworejo Tourism Village Program
}

\author{
Yohanes Putut Wibhisana \\ pututwibhisana@gmail.com \\ Mahasiswa Pascasarjana IImu Kesejahteraan Sosial \\ Fakultas IImu Sosial dan IImu Politik Universitas Indonesia
}

Naskah diterima: 3 September 2020 | Naskah direvisi: 19 Mei 2021 | Naskah diterbitkan: 30 Juni 2021

\begin{abstract}
Poverty is quite closely related to rural conditions, especially when comparing the life patterns of rural and urban communities, infrastructure development, and human resources. It is time for the people to become the subject of any poverty alleviation program. This paper aims to describe the process of community empowerment through the Jogoboyo Purworejo Tourism Village program by looking at planning strategies and developing tourist areas and seeing the impacts that arise in the development of these tourist areas. Purworejo Regency has various efforts to reduce poverty, one of which is a community empowerment program through tourism villages. This research uses a qualitative approach with descriptive research type. Data collection used in-depth interviews with six informants consisting of the district government, village officials, the tourism community, and local residents. The results showed that the community empowerment process was running quite well. Furthermore, community empowerment through the tourism village program that uses the community-based tourism scheme has a positive impact, where there is progress in the economic mindset, increasing new livelihoods, increasing income and financial management, as well as changes in work methods and behavior. However, efforts are needed to improve local human resources in the use of social media with content that attracts tourists. In addition, good coordination between local governments and local village communities that receive programs and communities engaged in tourism is also needed.
\end{abstract}

Keywords: community-based tourism; community empowerment; tourism villages

Abstrak: Kemiskinan cukup erat kaitannya dengan kondisi perdesaan, terlebih jika membandingkan pola kehidupan masyarakat perdesaan dan perkotaan, pembangunan infrastruktur serta sumber daya manusia (SDM). Sudah sepatutnya saat ini masyarakat menjadi subjek dalam setiap program pengentasan kemiskinan. Tulisan ini bertujuan untuk menggambarkan proses pemberdayaan masyarakat melalui program Desa Wisata Jogoboyo Purworejo dengan melihat strategi perencanaan dan pengembangan kawasan wisata serta melihat dampak yang muncul dalam pengembangan kawasan wisata tersebut. Kabupaten Purworejo memiliki berbagai upaya dalam mengurangi angka kemiskinan, salah satunya adalah program pemberdayaan masyarakat melalui desa wisata. Penelitian ini menggunakan pendekatan kualitatif dengan jenis penelitian deskriptif. Pengumpulan data menggunakan teknik wawancara mendalam dengan enam informan yang terdiri dari pihak pemerintah kabupaten, perangkat desa, 
komunitas pariwisata, dan warga setempat. Hasil penelitian menunjukkan proses pemberdayaan masyarakat berjalan dengan cukup baik. Selanjutnya pemberdayaan masyarakat melalui program desa wisata yang menggunakan skema communitybased tourism memberikan dampak positif, di mana ada kemajuan pola pikir ekonomi, pertambahan mata pencaharian baru, peningkatan pendapatan dan pengelolaan keuangan, serta perubahan cara dan perilaku kerja. Namun demikian, perlu upaya untuk meningkatkan SDM lokal dalam pemanfaatan media sosial dengan konten yang menarik perhatian wisatawan. Selain itu, koordinasi yang baik antara pemerintah daerah dengan masyarakat desa setempat yang menerima program dan komunitas yang bergerak di bidang pariwisata juga diperlukan.

Kata Kunci: desa wisata; pariwisata berbasis masyarakat; pemberdayaan masyarakat

\section{Pendahuluan}

Indonesia merupakan negara dengan kekayaan potensi alam yang sangat menjanjikan jika diolah dan dikembangkan untuk sektor pariwisata. Saat ini, sektor pariwisata merupakan salah satu sektor yang memiliki potensi besar untuk peningkatan pendapatan daerah. Namun, masih banyak daerah dengan potensi pariwisata yang tidak ditangani secara maksimal dan cenderung terabaikan. Pengembangan sektor pariwisata tentu saja sangat berkaitan dengan peningkatan kesejahteraan sosial suatu wilayah dan menjadi bagian dari pembangunan itu sendiri. Dalam pembangunan kesejahteraan sosial, sering kali ditemui permasalahan kesenjangan dan kemiskinan sebagai masalah utamanya. Padahal pembangunan sendiri memiliki tujuan untuk menciptakan suatu keadilan dan pemerataan.

Peningkatan konsumsi masyarakat berkaitan dengan peningkatan pendapatan dan peningkatan produksi. Hal ini menjadi sebuah patokan kesejahteraan suatu masyarakat, seperti adanya kesempatan kerja secara penuh bagi tiap orang, kesempatan untuk bersama-sama mengembangkan kemampuan, dan perekonomian yang seimbang. Kemiskinan dan kesenjangan merupakan sebuah masalah krusial yang tidak hanya dihadapi oleh Indonesia, namun juga dunia. Midgley (1995: 4) menjelaskan untuk mengatasi kemiskinan pada suatu negara, tentu saja harus dimulai dari lingkup terkecil yakni desa. Sayangnya pembangunan saat ini cenderung terfokus pada perkotaan dan melupakan pembangunan desa.

Menurut Badan Pusat Statistik (2020) di Indonesia belum ada pemerataan dan keadilan dalam pembangunan yang mengakibatkan kesenjangan antara si kaya dan si miskin menjadi sangat tinggi. Kesenjangan tersebut merupakan sebuah pembangunan yang terdistorsi, karena pembangunan ekonomi belum disertai dengan pembangunan sosial. Permasalahannya bukan karena tidak adanya pembangunan ekonomi, tetapi karena kegagalan menyelaraskan tujuan-tujuan pembangunan ekonomi dengan pembangunan sosial dan kegagalan menjangkau seluruh masyarakat dalam memberikan manfaat dari kemajuan ekonomi.

Salah satu bentuk pembangunan sosial yang pernah dilaksanakan oleh pemerintah untuk mengatasi kemiskinan di desa adalah Program Nasional Pemberdayaan Masyarakat (PNPM) Mandiri Pariwisata yang telah dijalankan sejak tahun 2009. Kementerian Pariwisata (Kemenpar, sejak tahun 2019 disebut Kementerian Pariwisata dan Ekonomi Kreatif atau Kemenparekraf) memberikan bantuan dana Rp150 juta untuk 569 desa yang saat ini dikembangkan menjadi desa wisata. Kemenpar (2015) memberikan alokasi anggaran sebanyak Rp453.777.486.115,00 untuk pengembangan destinasi wisata dan industri pariwisata pada rentang tahun 2015-2019. Alokasi dana tersebut diperuntukkan pada enam kegiatan, yaitu: (1) pengembangan infrastruktur dan ekosistem; (2) pengem- 
bangan destinasi wisata budaya; (3) pengembangan destinasi wisata alam dan buatan; (4) peningkatan kemitraan industri pariwisata; (5) peningkatan tata kelola destinasi dan pemberdayaan masyarakat setempat; dan (6) dukungan manajemen dan teknis lainnya.

Menurut Anwas (2013: 3) masyarakat didorong untuk memiliki kemampuan sesuai potensi dan kebutuhannya untuk berdiri tegak di atas kakinya sendiri, memiliki daya saing serta mandiri melalui berbagai kegiatan pemberdayaan. Pemberdayaan melalui pengembangan desa wisata juga menuntun masyarakat untuk dapat mengolah dan mengembangkan sumber daya alam yang ada di desanya dan mendorong peningkatan kreativitas dan inovasi dalam pemberdayaan sumber daya alam. Menurut Ife dan Toseriero (2006: 66-67), sumber daya, kesempatan, pengetahuan, dan keahlian perlu disiapkan guna meningkatkan kapasitas diri masyarakat dalam menentukan masa depannya. Selain itu, diperlukan partisipasi agar berpengaruh terhadap kehidupan masyarakat. Jika hal tersebut terpenuhi maka dapat disebut sebagai pemberdayaan (Anwas, 2013: 49).

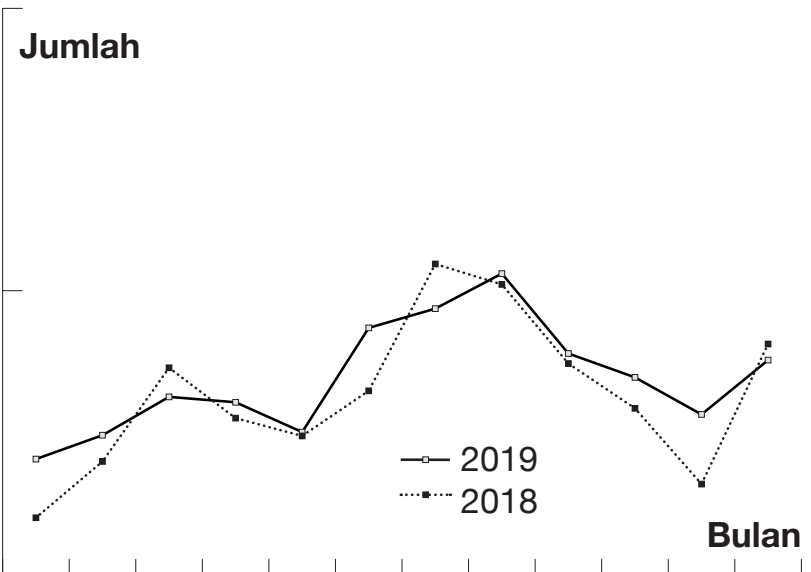

Jan Feb Mar Apr Mei Jun Jul Ags Sept Okt Nov Des

Bagan 1.

Data Kunjungan Wisatawan Mancanegara Per Bulan, 2018 dan 2019

Sumber: Kemenparekraf (2020)

Grafik jumlah wisatawan mancanegara yang datang ke Indonesia di tahun 2019 yang dirilis oleh Kemenparekraf menunjuk- kan adanya peningkatan dari tahun 2018 yang cukup tinggi, di mana total wisatawan pada tahun 2018 yakni 15.810.305 wisatawan dan pada tahun 2019 totalnya yakni 16.106.953 wisatawan (lihat Bagan 1). Kondisi ini cukup memberikan gambaran bagaimana prospek pariwisata di Indonesia yang cukup diminati oleh dunia.

Pengembangan desa wisata dengan berbagai inovasi dan keunikannya tentu saja dapat menjadi pilihan bagi wisatawan agar tidak merasa jenuh dengan wisata yang ada. Selain itu, sebagai bukti bahwa pendapatan daerah melalui sektor pariwisata menjadi devisa yang cukup menjanjikan, yakni target pendapatan asli daerah (PAD) sektor pariwisata Kabupaten Purworejo tahun 2019 terlampaui (Sudjatmiko, 2020). Seluruh objek wisata di wilayah itu menyumbang PAD Rp1,57 miliar, sedangkan APBD menargetkan pendapatan Rp1,43 miliar.

Salah satu daerah tujuan wisata yang terkenal baik di dalam maupun luar negeri adalah Provinsi Jawa Tengah, terutama dengan adanya Candi Borobudur di Kota Magelang yang pernah masuk sebagai salah satu dari tujuh keajaiban dunia. Namun, Candi Borobudur bukan satu-satunya daya tarik provinsi ini. Jawa Tengah juga memiliki Kabupaten Purworejo yang tengah mengembangkan program desa wisata karena letak geografisnya yang menawan.

Desa Wisata Jogoboyo merupakan salah satu desa wisata di Kabupaten Purworejo. Bagi sebagian masyarakat, Desa Wisata Jogoboyo mungkin masih terdengar asing. Namun demikian, dengan lokasi yang berada di sekitar jalur antarprovinsi DIY-Jawa Tengah, Desa Wisata Jogoboyo cukup mudah diakses oleh wisatawan yang hendak berlibur di sana. Posisi Kabupaten Purworejo berada di pinggiran Pantai Selatan sehingga terdapat banyak pantai yang bisa dikembangkan untuk pariwisata. Selain itu, kontur tanah yang berupa perbukitan juga menjadikan Purworejo memiliki beberapa curug 
(air terjun) yang cukup mengagumkan dan aliran sungai yang indah.

Sebagai sebuah destinasi wisata baru maka Desa Wisata Jogoboyo membutuhkan dukungan seluruh elemen masyarakat. Chambers (1995) menjelaskan bahwa pemberdayaan masyarakat setempat dan strategi untuk pemberdayaannya menjadi sangat penting, terutama mengingat desa wisata tersebut termasuk masih baru. Dalam hal ini, partisipasi masyarakat menjadi sangat krusial dan dominan jika menilik pada pemberdayaan masyarakat yang merupakan sebuah konsep pembangunan ekonomi yang merangkum nilai-nilai sosial. Konsep ini mencerminkan paradigma baru pembangunan, yakni bersifat people-centered, participatory, empowering, dan sustainable.

Berdasarkan uraian tersebut maka pertanyaan penelitiannya adalah: pertama, bagaimana proses pemberdayaan masyarakat melalui Program Desa Wisata Jogoboyo? Kedua, bagaimana dampak Program Desa Wisata Jogoboyo terhadap masyarakat setempat? Penelitian ini menggunakan pendekatan kualitatif dengan jenis penelitian deskriptif. Pengumpulan data menggunakan teknik wawancara mendalam dengan enam informan yang terdiri dari unsur pemerintah kabupaten, perangkat desa, komunitas pariwisata, dan warga setempat. Analisis data digunakan untuk membantu memahami keadaan di lapangan agar semakin mendekati realitas. Peneliti selanjutnya mengambil konsepkonsep yang terkait dengan topik penelitian, yang kemudian digunakan untuk menganalisis temuan lapangan yang diperoleh dari kegiatan wawancara.

\section{Pemberdayaan Masyarakat}

Pemberdayaan masyarakat merupakan kegiatan untuk meningkatkan kemampuan dan kemandirian masyarakat hingga mempunyai keberdayaan mengelola sumber daya agar dapat meningkatkan kesejahteraan dan keamanannya. Pemberdayaan masyarakat dalam prak- tiknya memberikan akses pada sumber daya, sosial budaya, politik, ekonomi, dan keamanan, sehingga masyarakat miskin dapat memanfaatkannya untuk meningkatkan kesejahteraan dan keamanan. Pemerintah sendiri menggunakan strategi pemberdayaan masyarakat sebagai upaya mengentaskan kemiskinan dan menyejahterakan masyarakat itu sendiri. Karena dengan pemberdayaan masyarakat berarti masyarakat tersebut didorong dan diminta untuk mengandalkan kemampuan kepemilikan.

Menurut Ife (2006: 182), pemberdayaan merupakan sebuah upaya meningkatkan daya, kesempatan, pengetahuan, keahlian dalam rangka meningkatkan kapasitas diri, menentukan masa depan, berpartisipasi dan memengaruhi kehidupan komunitas masyarakat sendiri. Sederhananya, pemberdayaan bertujuan meningkatkan keberdayaan kelompok yang tidak beruntung (the disadvantages group) seperti kelompok ras/entitas (kaum pribumi minoritas etnis dan kultural), kelompok kelas (miskin dan pengangguran). Pemberdayaan masyarakat prinsipnya adalah perubahan murni dari bawah dengan memanfaatkan sumber daya, pengetahuan, dan budaya lokal yang dimiliki untuk mencapai kesejahteraan bersama.

Ife (2006) menambahkan bahwa pemberdayaan merupakan upaya untuk meningkatkan daya dari kelompok yang kurang beruntung (disadvantaged people) atas pilihan pribadi dan kehidupan mereka (personal choices and life), kesempatan (chances), definisi kebutuhan (need definition), gagasan (ideas), institusi (institutions), sumber-sumber daya (resources), aktivitas ekonomi (economic activity), dan reproduksi (reproduction) dengan melakukan intervensi melalui pembuatan perencanaan dan kebijakan (policy and planning), aksi politik dan sosial (social and political action), serta pendidikan (education).

Dalam upaya pemberdayaan masyarakat khususnya kaum miskin dapat dilihat dari tiga sisi. Pertama, pemberdayaan 
dengan menciptakan suasana atau iklim yang memungkinkan potensi kaum miskin berkembang. Kedua, pemberdayaan untuk memperkuat peran kaum miskin dalam kehidupan bermasyarakat dan bernegara. Ketiga, pemberdayaan melalui pencegahan terjadinya persaingan yang tidak seimbang (Kartasasmita, 1996: 248).

Hal ini berarti bahwa setiap masyarakat, tanpa membedakan mereka dari golongan mana pun (khususnya masyarakat miskin), dapat memanfaatkan segala potensi yang ada di sekitarnya dan yang dimiliki untuk memperbaiki kehidupannya dan menuju ke arah kehidupan yang lebih baik. Selain itu, penting untuk meningkatkan kesadaran masyarakat miskin untuk mengetahui akses sumber daya yang tersedia yang terkait dengan proses pemberdayaan mereka. Pemberdayaan juga harus mencegah terjadinya persaingan yang tidak seimbang karena notabene masyarakat miskin cenderung lemah dalam aspek kehidupan. Oleh karena itu, pemberdayaan masyarakat miskin berkaitan dengan upaya penanggulangan masalah-masalah pembangunan, seperti halnya pengangguran, kemiskinan, dan kesenjangan.

Pembangunan dapat bervariasi berdasarkan tujuan pembangunan tersebut sehingga bentuk pemberdayaan bidang ekonomi (pemberdayaan ekonomi) belum tentu sama dengan pemberdayaan bidang budaya (pemberdayaan budaya) (Adi, 2013: 208). Pada dasarnya segala macam bentuk pemberdayaan masyarakat, seperti pemberdayaan politik, pemberdayaan sosial budaya, pemberdayaan lingkungan, pemberdayaan ekonomi, pemberdayaan kesehatan, pemberdayaan hukum, dan pemberdayaan spiritual saling berkaitan serta saling melengkapi dengan kesejahteraan sosial. Untuk tercapainya sebuah kesejahteraan sosial salah satunya diperlukan tuntasnya pemberdayaan bagi masyarakat tersebut. Selain itu, masingmasing pemberdayaan juga saling berkaitan, sebagai contoh pemberdayaan ekono- mi harus memperhatikan pemberdayaan sosial dan spiritual. Begitu pula dengan pemberdayaan yang lainnya juga harus saling berkaitan dan tidak dapat berjalan sendiri.

Pemberdayaan (empowerment) menurut Oxford English Dictionary memiliki dua arti, yakni "to give power or authority to" dan "to give ability to or enable". "To give power or authority to" dapat diartikan sebagai memberikan kekuasaan, mengalihkan kekuasaan atau mendelegasikan otoritas kepada pihak lain. Sementara itu, "to give ability to or enable" lebih diartikan sebagai upaya untuk memberikan kemampuan atau keberdayaan. Berdasarkan kedua pengertian tersebut, konsep pemberdayaan menjadi bagian dari upaya membangun eksistensi pribadi, keluarga, masyarakat, bangsa, pemerintahan, negara dan tata dunia di dalam kerangka proses aktualisasi kemanusiaan yang adil dan beradab.

Moeljarto (1996: 44-45) menjelaskan pemberdayaan mengandung dua kecenderungan. Pertama, proses pemberdayaan yang menekankan kepada proses memberikan atau mengalihkan sebagian kekuasaan, kekuatan atau kemampuan kepada masyarakat agar individu menjadi lebih berdaya. Proses ini dapat dilengkapi pula dengan upaya membangun aset material guna mendukung pembangunan kemandirian mereka melayani organisasi. Kecenderungan ini dapat disebut sebagai kecenderungan primer. Kecenderungan kedua atau kecenderungan sekunder menekankan pada proses menstimulasi, mendorong atau memotivasi individu yang mempunyai kemampuan atau keberdayaan untuk menentukan apa yang menjadi pilihan hidupnya melalui proses dialog.

Masyarakat miskin atau cenderung miskin lemah dalam segala bidang kehidupan bermasyarakat dan bernegara. Pemberdayaan kaum miskin berkaitan erat dengan upaya penanggulangan masalah-masalah pembangunan, seperti halnya pengangguran, kemiskinan, dan 
kesenjangan. Oleh karena itu, masalah dalam kehidupan mereka merupakan masalah pembangunan yang multidimensional. Masalah dalam kehidupan masyarakat miskin dapat menggunakan berbagai sudut pandang untuk menelaah kemiskinan dan langkah-langkah pemecahannya. Selain itu, dalam upaya penanggulangan kemiskinan pasti ada kaitannya dengan upaya pemerataan hasil pembangunan.

Dalam Dunia Ketiga pada masa 1950an dan 1970-an terdapat berbagai kebijakan pembangunan yang dilaksanakan dan bersifat top down serta bersifat growth oriented dan kurang memperhatikan secara langsung nasib golongan miskin baik yang tinggal di daerah perdesaan maupun perkotaan. Pemberdayaan masyarakat yang dilaksanakan oleh pemerintah memiliki tujuan dan citacita selain sebagai upaya mengentaskan kemiskinan, juga ikut memberdayakan masyarakat melalui proses atau gerak dari bawah.

Menurut Adi (2013: 212) pemberdayaan dapat dilihat dari sisi keberdayaannya yakni pemberdayaan sebagai suatu program dan suatu proses. Pemberdayaan sebagai suatu program berarti pemberdayaan dilihat dari tahap-tahap kegiatan guna mencapai suatu tujuan yang biasanya sudah ditentukan waktunya. Sementara pemberdayaan sebagai suatu proses menunjukkan pemberdayaan berkesinambungan sepanjang hidup seseorang (ongoing process), sepanjang komunitas itu masih ingin melakukan perubahan dan perbaikan, dan tidak hanya terpaku pada suatu program saja.

Berdasarkan beberapa teori di atas, secara garis besar pemberdayaan memiliki tujuan untuk menjadikan masyarakat dapat meningkatkan aspek-aspek dalam kehidupannya. Dalam proses pemberdayaan itu sendiri, menurut Adi (2013: 231) memerlukan program sebagai alat pencapaian tujuan dan memerlukan proses untuk kesinambungan berjalannya pemberdayaan. Sementara, jika merujuk pada apa yang disampaikan oleh Ife dan Toseriero (2006) lebih mengutamakan pada bagaimana mempersiapkan segala sesuatunya bagi masyarakat guna proses pemberdayaan bagi mereka sendiri dan tergantung pula pada bagaimana partisipasi mereka.

Dalam pemberdayaan masyarakat, partisipasi masyarakat merupakan hal yang paling penting dan erat kaitannya dengan keberhasilan sebuah program pemberdayaan masyarakat. Menurut Mikkelsen (2005: 53-54) istilah partisipasi dan partisipatoris biasanya digunakan di masyarakat dalam berbagai makna umum seperti berikut: (1) partisipasi adalah kontribusi sukarela dari masyarakat dalam suatu proyek (pembangunan), tetapi tanpa mereka ikut terlibat dalam proses pengambilan keputusan (participation is the voluntary contribution by people in projects hut without their taking part in decisionmaking); (2) partisipasi adalah kepekaan orang untuk meningkatkan penerimaan dan kemampuan mereka untuk menanggapi proyek pembangunan (participation is the sensitization of people to increase their receptivity and ability to respond to development projects); (3) partisipasi adalah proses aktif, artinya orang atau kelompok yang bersangkutan mengambil inisiatif dan menegaskan otonomi untuk melakukannya (participation is an active process, meaning that the person or group in question takes initiative and asserts the autonomy to do so); (4) partisipasi adalah proses menjembatani dialog antara komunitas lokal dengan pihak penyelenggara proyek dalam rangka persiapan, implementasi, pemantauan, dan evaluasi staf agar dapat memperoleh informasi tentang konteks sosial ataupun dampak sosial proyek terhadap masyarakat (participation is the fostering of a dialogue between the local people and the project or programme preparation, implementation, monitoring and evaluation staff in order to obtain information on the local context and on social impacts); (5) partisipasi adalah keterlibatan masyarakat secara sukarela dalam peru- 
bahan yang ditentukan sendiri oleh masyarakat (participation is the voluntary involvement of people in self-determined change); (6) partisipasi adalah keterlibatan masyarakat dalam upaya pembangunan lingkungan, kehidupan, dan diri mereka sendiri (participation is involvement in people's development of themselves, their lives, and their environment).

\section{Community-Based Tourism}

Dalam proses pemberdayaan masyarakat yang ditujukan pada sektor desa wisata, community-based tourism merupakan sebuah sarana atau cara yang cukup penting bagi pengembangan pariwisata. Menurut Häusler (2005: 1-2) community-based tourism merupakan bentuk dari pariwisata yang memberikan kesempatan kepada masyarakat lokal untuk mengontrol dan terlibat dalam manajemen dan pengembangan pariwisata dan di dalamnya terdapat tiga unsur penting yakni: (1) keterlibatan masyarakat lokal dalam manajemen dan pengembangan pariwisata; (2) pemerataan akses ekonomi bagi seluruh lapisan masyarakat; serta (3) pemberdayaan politik (capacity building) masyarakat lokal yang bertujuan meletakkan masyarakat lokal sebagai pengambil keputusan.

Sementara, menurut Anstrand (2006: 14) community-based tourism merupakan bentuk pariwisata yang memperhitungkan dan menempatkan keberlanjutan lingkungan, sosial, dan budaya, diatur dan dimiliki oleh komunitas, untuk komunitas. Aspek pengembangan kapasitas komunitas dan lingkungan menjadi inti dan prioritas baru kemudian menuju ke aspek ekonomi, sementara aspek ekonomi menjadi imbas atau akibat dari aspek sosial, budaya, dan lingkungan. Pemberdayaan masyarakat yang berpedoman pada community-based tourism pada dasarnya memiliki tujuan untuk menyelesaikan permasalahan kemiskinan, khususnya kemiskinan di perdesaan. Dengan adanya pemberdayaan masyarakat ini akan terjadi kesinambungan perekonomian komunitas atau masyarakat setempat.

Optimalisasi sumber daya manusia (SDM), sumber daya alam (SDA), infrastruktur, dan inovasi pariwisata menjadi poin penting sebagai medianya. SDM menjadi kesatuan dengan SDA untuk peningkatan pengelolaan dan pengolahannya. Setelah semua terlaksana, kemudian dilihat bagaimana hasil dari pemberdayaan masyarakat tersebut dan dampaknya bagi masyarakat.

\section{Program Desa Wisata Jogoboyo sebagai Strategi Pemberdayaan Masyarakat}

Pemberdayaan masyarakat melalui program Desa Wisata Jogoboyo merupakan sebuah strategi yang diimplementasikan kepada masyarakat guna meningkatkan taraf kehidupan masyarakat setempat agar lebih baik atau bisa juga disebut sebagai sarana pengentasan kemiskinan. Program pemberdayaan masyarakat melalui desa wisata merupakan upaya masyarakat untuk berperan aktif dalam berbagai kegiatan pariwisata di daerahnya, mulai dari perencanaan, pelaksanaan, sampai pengelolaan kegiatan wisata berkelanjutan. Strategi pemberdayaan masyarakat juga dibutuhkan untuk mengorganisir segala bentuk upaya pengembangan pariwisata. Dengan demikian, diharapkan kegiatan pariwisata yang memberdayakan masyarakat akan menciptakan lapangan kerja dan akan menjadi kegiatan yang sustainable.

Desa Jogoboyo merupakan salah satu dari 40 desa di Kecamatan Purwodadi. Desa Jogoboyo berada paling ujung selatan Kecamatan Purwodadi yang berhadapan langsung dengan Samudera Hindia dan Kabupaten Kulon Progo. Desa Jogoboyo memiliki luas wilayah 126,6 ha terdiri dari 9 Rukun Tetangga (RT) dan 2 Rukun Warga (RW) dengan total penduduk sekitar 1.700 jiwa. Akses menuju pusat perkotaan seperti Kabupaten Purworejo maupun Kota Yogyakarta cukup jauh. 
Namun demikian, Desa Joyoboyo memiliki nuansa pedesaan dengan bentangan persawahan dan tata hunian khas perdesaan.

Di Desa Jogoboyo terdapat empat pedukuhan, yakni Kauman, Semanggi, Kasokan, dan Krajan. Desa Wisata Jogoboyo sendiri berada di dalam kawasan Kecamatan Purwodadi, kecamatan yang juga berbatasan dengan Kabupaten Kulon Progo yang saat ini menjadi sorotan karena telah didirikan bandara internasional baru. Pertumbuhan penduduk di Desa Jogoboyo cenderung stabil, tidak pernah terjadi penurunan ataupun lonjakan yang signifikan. Sebagian besar wilayah Jogoboyo merupakan persawahan dengan pengairan berasal dari Sungai Bogowonto dan menjadi hilir dari aliran sungai Bogowonto yang langsung bermuara ke Samudera Hindia. Sungai Bogowonto menjadi salah satu daya tarik dan aset wisata yang dikembangkan oleh masyarakat sekitar.

Desa Wisata Jogoboyo beruntung karena dibangunnya Yogyakarta International Airport (YIA). Dengan potensi ini tentu saja akan menjadi sebuah peluang dan motivasi bagi Desa Jogoboyo untuk mengembangkan daerahnya, karena YIA yang notabene bandara internasional memiliki beberapa rute penerbangan baik dari dalam maupun dari luar negeri. Hal ini menjadikan daerah sekitar Desa Wisata Jogoboyo sebagai sasaran investor terutama di bidang usaha perhotelan, kuliner, dan pariwisata.

Dalam menjalankan roda pariwisata yang diinisiasi oleh masyarakat dan komunitas tentu saja terfokus pada halhal yang menjadi potensi pada Desa Wisata Jogoboyo. Masyarakat Desa Wisata Jogoboyo sebagian besar berprofesi sebagai petani padi, petani sayuran, dan nelayan ikan. Sembari mengembangkan potensi lingkungan, masyarakat Desa Wisata Jogoboyo juga mensinergikan profesinya menjadi cikal bakal pariwisata. Dari kegiatan bertani muncul kegiatan agrowisata, sedangkan kegiatan nelayan dan perikanan berpotensi menjadi wisata kuliner hasil laut, wisata perahu, serta kegiatan wisata beraroma kebudayaan dan seni.

Desa Wisata Jogoboyo banyak dikunjungi oleh warga dari luar desa maupun luar kota yang ingin berlibur atau berwisata secara langsung, baik untuk menikmati wisata alam, wisata kuliner, maupun festival kesenian yang ada di daerah tersebut. Potensi tersebut kemudian dikembangkan oleh beberapa komunitas masyarakat yang bersinergi dengan pihak-pihak terkait khususnya dinas pariwisata untuk membuka perkampungan mereka sebagai arena wisata dan diberi sebutan desa wisata. Wisatawan yang datang akan disuguhkan berbagai kegiatan yang membuat mereka dekat dengan kehidupan pedesaan, pertanian, alam yang asri, dan kegiatan seni kebudayaan tradisional.

Desa Jogoboyo sendiri merupakan desa yang dikelilingi oleh perairan, baik sungai maupun samudra. Hulu Sungai Bogowonto berada di Pegunungan Menoreh dan hilirnya di pantai Selatan merupakan salah satu dari empat sungai besar di Provinsi Jawa Tengah. Walaupun sungai tersebut memiliki sejarah yang sangat panjang bagi masyarakat Purworejo, namun sebelumnya tidak ada perayaan apapun yang berkaitan dengan Sungai Bogowonto hingga akhirnya muncul sebuah festival yang diadakan oleh Desa Jogoboyo selaku desa yang dilewati oleh aliran sungainya.

Festival Bogowonto digelar sebagai wujud syukur dan bentuk nyata dari kepedulian dan kesadaran untuk mengingatkan perilaku manusia agar ramah dan sayang kepada sungai dan alam. Festival Bogowonto mengusung aneka seni budaya sebagai tanda kehidupan peradaban manusia dan kecintaan manusia air, sang sumber kehidupan. Festival Jogoboyo berisikan kegiatan seni dan budaya dalam sebuah rangkaian wisata alam, sejarah, dan seni budaya, kuliner, dan keanekaragaman hayati Kabupaten Purwore- 
jo. Festival ini melibatkan seluruh lapisan masyarakat guna membangkitkan kembali kecintaan akan kelestarian sungai dan alam.

Festival Bogowonto merupakan salah satu sarana pemberdayaan masyarakat Desa Jogoboyo yang kemudian berkolaborasi dengan pihak-pihak luar. Hal ini dikuatkan oleh pernyataan penggagas Festival Bogowonto yang menjadi cikal bakal Desa Wisata Jogoboyo, yakni kondisi geografis Desa Jogoboyo yang berada pada jalur perlintasan utama, merupakan salah satu faktor pendukung yang mampu mendatangkan pengunjung pada pusat oleh-oleh tersebut. Hal ini didukung oleh pernyataan dari salah satu narasumber yang merupakan seniman penggagas Festival Bogowonto di Desa Jogoboyo yakni Bapak RO,

"secara geografis Kali Bogowonto itu kuat banget, home industry-nya kuat juga seperti camilan atau makanan, karena ini jalur perlintasan utama ya dan harus ada pusat oleh-oleh".

Festival Bogowonto membuat Desa Wisata Jogoboyo lebih dikenal oleh khalayak luas. Festival ini melibatkan seluruh lapisan masyarakat guna membangkitkan kembali kecintaan akan kelestarian sungai dan alam.

Konservasi, edukasi, dan rekreasi menjadi tema besar siap diusung warga untuk saling mengedukasi, saling mendukung membuat tempat yang nyaman rekreatif dengan mencintai sungai, terlebih sungai Bogowonto yang berada di Desa Wisata Jogoboyo adalah sungai muara yang langsung menghubung ke Pantai Jetis. Festival ini menjadi daya tarik untuk wisatawan agar berkunjung ke desa wisata tersebut dan sarana memperkenalkan desa wisata kepada masyarakat luas. Pengunjung festival akan menikmati langsung kearifan lokal desa Jogoboyo, aneka sajian kuliner, kesenian, budaya, hasil-hasil pertanian beserta olahannya yang disajikan, seperti gula aren dan gula jawa yang khas dari Desa Wisata Jogoboyo.
Festival tersebut memberikan sarana belajar dan praktik langsung bagi masyarakat Desa Wisata Jogoboyo dalam kegiatan pariwisata. Kegiatan yang diadakan maupun program yang masuk ke desa tersebut menjadi sarana pemberdayaan masyarakat setempat khususnya di bidang pariwisata. Jikalau sebelumnya masyarakat memiliki kegiatan atau pekerjaannya masing-masing, kini mereka memiliki tambahan kegiatan guna mendukung perekonomian mereka serta membuat mereka berdaya atas apa yang mereka miliki baik SDA maupun potensi SDM.

Terdapat lima proses yang dilalui Desa Wisata Jogoboyo dalam mengimplementasikan program desa wisata, yaitu: pertama, melakukan penguatan relasi kepada masyarakat dan penyusunan regulasi; kedua, mengkaji potensi dan alternatif yang bisa dikerjasamakan untuk perubahan; ketiga, menyusun rencana kegiatan pengembangan ekonomi lokal melalui pariwisata berbasis masyarakat; keempat, mengimplementasikan pengembangan ekonomi lokal melalui pariwisata berbasis masyarakat; kelima, melakukan monitoring dan evaluasi.

Pada mulanya ada rasa tidak percaya diri akan kemampuan SDM, namun dengan dukungan dari pihak pemerintah dan komunitas dari luar desa, maka proses membangun relasi bisa berjalan dengan baik. Selain itu, pimpinan desa berusaha bekerja sama dengan semua elemen desa. Dengan kondisi SDM yang terbatas, maka penguatan relasi tidak hanya dilakukan dalam kaitan mendukung program yang ada di komunitas, namun juga bagaimana komunitas itu dapat berdaya guna dengan pelibatan di berbagai kegiatan dan menumbuhkan rasa kepemilikan serta rasa percaya diri bahwa semua bisa dilakukan bila ada kerja sama.

Pada Desa Wisata Jogoboyo, community-based tourism bersinergi dan merupakan sebuah jembatan dalam pemberdayaan masyarakat. Langkah awal yang menjadi sangat penting dalam proses 
pengembangan ekonomi lokal melalui pariwisata berbasis masyarakat adalah relasi dan regulasi. Kedua hal ini perlu berjalan beriringan di awal karena sama-sama saling memperkuat untuk proses selanjutnya. Community-based tourism yang basisnya yakni komunitas menjadi penggerak bagi semua elemen yang ada di masyarakat guna belajar bersama-sama, melihat apa kelebihan dan kekurangannya. Dalam perjalanannya, komunitas yang terbentuk di Desa Wisata Jogoboyo menjadi sebuah media bagi masyarakat untuk berinovasi serta bergandengan bersama pemerintah kabupaten ataupun dinas pariwisata setempat guna mengembangkan daerahnya di bidang pariwisata. $\mathrm{Hal}$ ini pula dilihat oleh warga serta komunitas pariwisata atau kelompok sadar wisata (pokdarwis) sebagai upaya positif.

Selaras dengan enam aspek partisipasi masyarakat dalam pemberdayaan masyarakat yang diutarakan oleh Mikkelsen (2005: 53-54), maka implementasinya terlihat sebagai berikut: pertama, partisipasi adalah kontribusi sukarela dari masyarakat dalam suatu proyek (pembangunan), tetapi tanpa mereka ikut terlibat dalam proses pengambilan keputusan. Partisipasi yang terjadi di Desa Wisata Jogoboyo terjadi dan timbul tanpa adanya paksaan dan intimidasi karena masyarakat setempat sadar bahwa program tersebut akan berdampak positif bagi perkembangan dan pembangunan daerah mereka. Namun, karena ditetapkannya program desa wisata merupakan prakarsa dari pemerintah daerah, maka pengambilan keputusan awal tidak melibatkan masyarakat. Mereka baru akan terlibat setelah program desa wisata tersebut berjalan dan disepakati untuk dijalankan.

Kedua, partisipasi adalah proses membuat masyarakat menjadi lebih peka. Di Desa Wisata Jogoboyo, masyarakat setempat menjadi peka terhadap potensi yang ada di lingkungan mereka, baik potensi SDA maupun SDM. Mereka bersa- ma komunitas dan pemerintah daerah membuat produk wisata dari potensi desa.

Ketiga, partisipasi adalah suatu proses aktif, yang bermakna bahwa orang ataupun kelompok yang terlibat mengambil inisiatif dan mempunyai otonomi untuk melakukan hal itu. Warga Desa Wisata Jogoboyo berdasarkan kepekaan mereka akan kegiatan pariwisata yang memiliki dampak positif bagi perekonomian mereka, menjadi aktif berpartisipasi dalam pengembangan dan pembangunan desa wisata di daerah mereka dengan berinisiatif ikut serta dalam berbagai bentuk pelatihan dan program yang diadakan oleh komunitas, pemerintah Kabupaten Purworejo, Dinas Pariwisata Purworejo, dan pokdarwis Desa Jogoboyo.

Keempat, partisipasi adalah proses menjembatani dialog antara komunitas lokal dengan pihak penyelenggara proyek dalam rangka persiapan, implementasi, pemantauan, dan evaluasi staf agar dapat memperoleh informasi tentang konteks sosial ataupun dampak sosial proyek terhadap masyarakat. Dalam hal ini, partisipasi masyarakat Desa Jogoboyo, komunitas penggiat pariwisata, ataupun pokdarwis, dan Pemerintah Kabupaten Purworejo, beserta Dinas Pariwisata Kabupaten bersinergi dalam berbagai tahapan baik persiapan program, pelaksanaan (dalam kegiatan pariwisata seperti Festival Bogowonto), dan evaluasi jalannya kegiatan maupun program. Hal ini berjalan karena adanya partisipasi dari pihak-pihak tersebut yang menjadi jembatan dalam program desa wisata.

Kelima, partisipasi adalah keterlibatan masyarakat secara sukarela dalam perubahan yang ditentukan sendiri oleh masyarakat. Masyarakat Desa Wisata Jogoboyo terlibat sejak awal dicanangkannya program desa wisata dengan kesadaran penuh akan dampak positif yang akan mereka terima. Kontribusi mereka berupa keterlibatan dalam persiapan pembangunan infrastruktur desa guna menjadi desa wisata, kemudian dalam pengelo- 
laan pariwisata, dan dalam berinovasi serta evaluasi program desa wisata.

Keenam, partisipasi adalah keterlibatan masyarakat dalam upaya pembangunan lingkungan, kehidupan, dan diri mereka sendiri. Dalam hal ini, masyarakat sebagai orang yang "berdiri" di atas "rumah"-nya sendiri, yakni Desa Jogoboyo, keterlibatannya seolah menjadi hal lumrah terlebih tempat tinggalnya juga sebagai tempat mencari nafkah. Partisipasi masyarakat Desa Jogoboyo dengan terlibat dalam program desa wisata menjadi bukti bahwa mereka dalam proses pemberdayaan dan menuju ke tahap sebagai masyarakat yang berdaya atas sumber daya yang mereka miliki melalui jalur pariwisata.

\section{Dampak Pengaplikasian Community- Based Tourism Melalui Program Desa Wisata}

Menurut Häusler (2005: 1-2), manfaat penerapan community-based tourism khususnya desa wisata adalah memberikan keuntungan bagi masyarakat, bahkan bagi mereka yang tidak terlibat langsung. Community-based tourism akan melibatkan masyarakat lokal secara langsung dari segala fungsi, baik fungsi pelaksanaan, pengembangan, dan pengawasan. Setidaknya terdapat beberapa hal, jika tidak seluruhnya, dampak dan manifestasi dari pariwisata berbasis komunitas Desa Wisata Jogoboyo dengan mengacu pada sejumlah definisi dan manfaat dari pemberdayaan masyarakat tersebut.

Pendekatan yang menguntungkan masyarakat yang dapat terlihat yakni: pertama, memberikan kesempatan kepada masyarakat lokal untuk mengontrol dan terlibat di dalam manajemen dan pembangunan pariwisata. Hal ini sedikit banyak dapat terlihat pada Desa Wisata Jogoboyo. Hal ini pun sesuai dengan pernyataan warga Desa Jogoboyo yakni Ibu SR,

"kalau SDA sudah ga perlu diragukan lagi ya dengan potensi alam kita sungai, pantai, kalau SDM pinginnya semua pinter teredukasi dengan pela- tihan-pelatihan, pemerintah desa sudah kasih fasilitas karena juga mereka yang punya wewenang, yang banyak gerak PKK, kalau pokdarwis masih baru, kalau karang taruna malah banyak terlibat. Contohnya dulu PKK selalu dapat anggaran dari pemda."

Tetapi di sisi lain dalam proses pengelolaan dan pengembangannya masyarakat memerlukan asistensi dari pihak eksternal agar dapat meningkatkan kapasitas dalam proses alih pengetahuan yang intensif.

Kedua, masyarakat yang tidak terlibat langsung dalam usaha pariwisata juga mendapat keuntungan. Sejumlah masyarakat desa memanfaatkan Desa Wisata Jogoboyo untuk memperoleh keuntungan ekonomi dengan berdagang. Dalam hal ini seperti pernyataan warga Desa Jogoboyo lbu SR,

"Kan lumayan sebenernya nelayan sambilannya bawa turis, petani sambilannya mendampingi turis, kan lumayan. Ya yang sejahtera karena memang tambaknya memang taninya."

Pernyataan tersebut menunjukkan bahwa terdapat dampak positif community-based tourism dari segi ekonomi.

Ketiga, menuntut pemberdayaan secara politis, demokratis, dan distribusi keuntungan kepada komunitas yang kurang beruntung di perdesaan. Hal ini selaras dengan salah satu pernyataan Dinas Pariwisata Purworejo yang mengharapkan pergerakan komunitas untuk memajukan desa wisata ini. Menurut narasumber yang mewakili Dinas Pariwisata Purworejo yakni Ibu WR,

"Seni budaya yang nantinya dapat menjadi daya tarik kunjungan wisatawan pada Desa Jogoboyo. Dari komunitas, kita hanya support. Ya seperti ngayogjazz ya mas, kita ga bisa instan menikmati, butuh proses, apalagi baru setahun."

Terkait hal ini, pemberdayaan secara politis dan demokratis masih memerlukan perhatian karena merupakan sebuah proses yang berlangsungnya dalam jang- 
ka waktu yang panjang, terus-menerus, dan melibatkan seluruh pihak yang terlibat dalam pengembangan Desa Wisata Jogoboyo. Perlu menjadi catatan bahwa jika upaya pemberdayaan masyarakat tidak dikelola dan direncanakan dengan baik oleh seluruh pemangku kepentingan yang ada, terlebih apabila distribusi manfaat ekonomi dan partisipasi tidak menyentuh sebagian besar elemen masyarakat desa, maka rentan menjadi pemicu permasalahan, baik yang bersifat horizontal maupun vertikal.

Permasalahan sosial horizontal salah satunya dapat berupa kecemburuan sosial sebagai akibat dari distribusi manfaat ekonomi yang tidak merata dari hasil pariwisata. Sementara itu, permasalahan sosial vertikal terkait relasi antara masyarakat desa dengan pemerintahan desa, pemerintahan kabupaten, dan pemangku kepentingan lainnya yang terlibat di dalam pengembangan Desa Wisata Jogoboyo.

Community-based tourism menurut Anstrand (2006: 14) merupakan bentuk pariwisata yang memperhitungkan dan menempatkan keberlanjutan lingkungan, sosial dan budaya, diatur dan dimiliki oleh komunitas, untuk komunitas, serta pemberdayaan masyarakat. Community-based tourism pada dasarnya memiliki tujuan sebagai upaya penanganan permasalahan kemiskinan khususnya kemiskinan di perdesaan. Pada pemberdayaan masyarakat di Desa Jogoboyo melalui program desa wisata menjadikan program tersebut sebagai program yang sustainable atau berkelanjutan, di mana kegiatan pariwisata di Desa Jogoboyo yang merupakan program berkelanjutan dan menyasar pada lingkungan yang ada yakni alam dan lingkungan desa, kehidupan bermasyarakat dengan kearifan lokal yang menjadi daya tarik pula, serta kebudayaan identitas Desa Jogoboyo yang juga memiliki keunikan dan ciri khas.

Semua hal tersebut tentu saja milik dari Desa Jogoboyo yang kemudian diatur oleh warga desa pula yang kemudian memben- tuk komunitas baru di bidang pariwisata yakni pokdarwis. Komunitas ini sebagai media yang menjembatani kebijakan dari pemerintah daerah atau pun instansi yang berkaitan serta pihak swasta yang kemudian akan masuk ke dalam jalannya program desa wisata. Komunitas (Pokdarwis Desa Wisata Jogoboyo) yang bergerak dan berafiliasi dengan berbagai macam instansi membuat berbagai kegiatan pariwisata seperti Festival Bogowonto, agrowisata, wisata perahu, wisata kuliner, menjadi sebuah upaya untuk membantu perekonomian warga setempat yang pada ujungnya mengatasi permasalahan kemiskinan yang ada di desa tersebut.

Program ini tidak berhenti pada satu kegiatan saja, tetapi program ini kemudian menjadi bahan dan pemicu bagi masyarakat setempat untuk melanjutkan program ini baik bekerja sama dengan investor swasta maupun pemerintah. Keikutsertaan dan keterlibatan masyarakat adalah upaya langsung agar program ini merata dan warga yang belum memiliki pekerjaan tetap dan memiliki waktu luang dapat berkecimpung dalam kegiatan pariwisata dan tentu saja memengaruhi perekonomian mereka juga.

\section{Program Desa Wisata Jogoboyo sebagai Strategi Pemberdayaan Masyarakat}

Partisipasi masyarakat yang terjadi di Desa Wisata Jogoboyo berjalan dengan sendirinya tanpa ada paksaan dari pihak mana pun. Partisipasi ini muncul karena adanya kesadaran dari masyarakat setempat bahwa program tersebut akan berdampak positif bagi perkembangan dan pembangunan daerah mereka.

Yang terjadi saat ini adalah masyarakat setempat menjadi lebih menyadari terhadap potensi yang ada di lingkungan mereka, baik potensi SDA maupun SDM. Kesadaran tersebut berdampak pada partisipasi aktif masyarakat dalam pengembangan dan pembangunan fisik desa wisata di daerah mereka. Selain itu, masyarakat 
juga menyadari pentingnya pengembangan dari sisi peningkatan kualitas SDM, yaitu dengan berinisiatif ikut serta dalam berbagai bentuk pelatihan dan program yang diadakan oleh komunitas, pemerintah Kabupaten Purworejo, Dinas Pariwisata Purworejo, dan Pokdarwis Desa Jogoboyo.

Lebih dari itu, telah tercipta sinergi antara masyarakat Desa Jogoboyo dengan komunitas penggiat pariwisata ataupun pokdarwis, dan Pemerintah Kabupaten Purworejo beserta Dinas Pariwisata Kabupaten dalam tahap persiapan program, pelaksanaan (dalam kegiatan pariwisata seperti Festival Bogowonto), dan evaluasi jalannya kegiatan maupun program. Partisipasi masyarakat Desa Jogoboyo dengan terlibat dalam program desa wisata menjadi bukti bahwa mereka dalam proses pemberdayaan dan menuju ke tahap sebagai masyarakat yang berdaya atas sumber daya yang mereka miliki melalui jalur pariwisata.

\section{Penutup}

Secara ringkas, pemberdayaan masyarakat berbasis aset berfokus pada segala bentuk potensi sumber daya yang melekat pada masyarakat dan lingkungannya yang dapat dikembangkan lebih lanjut sebagai media untuk meningkatkan kesejahteraan masyarakat. Bentuk pemberdayaan komunitas yakni community-based tourism dengan pendekatan pemberdayaan komunitas berbasis aset mendorong identifikasi dan pemanfaatan berbagai sumber daya antara lain: kultural, natural, sumber daya manusia, politik, infrastruktur, dan finansial yang melekat di masyarakat. Upaya pemberdayaan masyarakat Desa Wisata Jogoboyo dipandang masih berfokus pada pengembangan sumber daya yang bersifat tangible.

Di sisi lain, identifikasi dan pengembangan terhadap potensi sumber daya yang melekat pada masyarakat desa yang dapat terkait dengan pariwisata belum mendapat perhatian yang cukup dari sejumlah pemangku kepentingan dalam pengembangan Desa Wisata Jogoboyo.

Proses pemberdayaan masyarakat berbasis pada community-based tourism di Desa Wisata Jogoboyo Purworejo berjalan cukup baik. Namun demikian, saat ini Desa Wisata Joyoboyo masih dalam proses perintisan. Pokdarwis dan Badan Usaha Milik Desa (BUMDes) didirikan untuk mendukung pariwisata berbasis masyarakat di Desa Jogoboyo dan menjadi sarana untuk berinovasi masyarakat. Komunitas tadi berkontribusi dan memberi manfaat positif bagi kreativitas masyarakat, memberi stimulus penggerak semangat kemajuan ekonomi, dan membentuk sebuah hubungan interaksi antara berbagai stakeholder sebagai media perubahan ke arah yang lebih baik.

Proses pemberdayaan masyarakat melalui community-based tourism terhadap kesejahteraan ekonomi masyarakat memberikan dampak yang sangat positif, karena memberikan kemajuan pola pikir perekonomian. Dengan penerapan community-based tourism, maka ada pemerataan mata pencaharian baru di dalam komunitas desa dan peningkatan pendapatan. Selain itu, berdasar pada skema komunitas maka terbentuklah sistem pengelolaan keuangan serta manajemen kerja. Dampak tersebut berkorelasi dengan meningkatnya penghasilan masyarakat Desa Jogoboyo.

Desa Wisata Jogoboyo memiliki potensi ekonomi lokal, komunitas, SDA, juga mempunyai faktor keberuntungan dari destinasi wisata, yaitu memiliki akses yang sangat dekat dengan Yogyakarta International Airport, di mana destinasi wisata lain cenderung jauh dari akses lalu lintas transportasi internasional. Desa Wisata Jogoboyo mempunyai keunikan dan keunggulan destinasi yang dapat dikomparasi dengan destinasi lain yang ada di sekitarnya, misalnya adanya mangrove, Sungai Bogowonto, Pantai Jetis, dan keasrian lingkungan. Kondisi SDM di Desa Wisata Jogoboyo masih perlu ditingkatkan 
dengan fasilitasi berbagai pelatihan karena masyarakat setempat masih terhitung baru dalam menghadapi dunia pariwisata dan belum berpengalaman dalam pengelolaan dan kreativitas pariwisata.

Peran pemerintah adalah membuat regulasi dan dapat berjalan beriringan atau bersinergi dengan pokdarwis dan BUMDes. Pemerintah desa juga perlu menyusun peraturan desa untuk mengatur tata ruang dan wilayah desa agar tidak seluruh tanah di desa dapat dijual kepada pihak luar mengingat lokasi di sekitar bandara menjadi daya tarik investor. Selain adanya peraturan Hak Guna Usaha dengan pengelolaan destinasi yang bekerja sama dengan BUMDes dan komunitas pengelolaan wisata desa.

Bagi komunitas, komunitas belum cukup solid untuk mengembangkan pariwisata daerahnya. Oleh karena itu, diperlukan banyak pelatihan dan pendampingan dalam mengelola pariwisata dan mengajak komunitas lain untuk mengembangkan potensi dan wilayah dengan (ciri khas) keunggulan tertentu. Untuk Dinas Pariwisata dan Kebudayaan Kab. Purworejo, diharapkan dapat menjalin hubungan kemitraan, tidak hanya dengan kelompok seniman tetapi juga dengan lembaga swadaya masyarakat atau bahkan pelaku industri pariwisata untuk memfasilitasi pengembangan komunitas. Bagi Pemerintah Kabupaten Purworejo dan Dinas Pariwisata agar kelompok seniman lebih dipandang berfokus pada Festival Bogowonto.

Sementara itu, pemberdayaan komunitas membutuhkan pengembangan terhadap potensi lainnya yang dapat difasilitasi LSM maupun pelaku industri pariwisata. Sejumlah pelaku industri pariwisata memiliki prospek dalam pengembangan pariwisata berbasis komunitas Desa Wisata Jogoboyo antara lain: pemandu wisata di Yogyakarta, industri travel, dan pengelola objek destinasi lainnya di sekitar Desa Jogoboyo untuk pemasaran dan pengembangan paket wisata bagi wisatawan.
Yang terakhir, diharapkan untuk DPR RI, khususnya Komisi $X$ yang ruang lingkupnya bidang pendidikan, olahraga, pariwisata, dan ekonomi kreatif dapat memberikan perhatian khusus pada pengembangan Desa Wisata Jogoboyo Purworejo, mengingat lokasinya sangat dekat dengan lalu lintas bandara internasional, dimana hal tersebut akan menjadi destinasi wisata yang terdekat bagi wisatawan internasional yang akan melewati daerah tersebut. Anggota DPR RI juga perlu menyerap aspirasi dari masyarakat setempat, mendorong pemerintah untuk melaksanakan program-program pengembangan pariwisata, kemudian melakukan pengawasan terhadap implementasi di lapangan.

\section{Daftar Pustaka}

Adi, I. R. (2013). Intervensi komunitas dan pengembangan masyarakat. Jakarta: PT Raja Grafindo Persada.

Anstrand, M. (2006). Community-based tourism and socio-culture aspect relating to tourism a case study of a Swedish student excursion to Babati (Tanzania) [Tesis]. Södertörn University College, School of Life Sciences. Huddinge. Diakses dari http://www.diva-portal.org/smash/record. jsf?pid=diva2\%3A16436\&dswid $=7896$

Anwas, O. M. (2013). Pengembangan masyarakat di era global. Bandung: Alfabeta.

Badan Pusat Statistik. (2020). Penduduk Miskin Pedesaan Perkotaan Menurut Provinsi. Jakarta: Badan Pusat Statistik.

Chambers, R. (1988). Pembangunan desa mulai dari belakang. Jakarta: LP3ES.

Garrod, B. (2003). Local participation in the planning and management of ecotourism: a revised model approach. Journal of Ecotourism, 2(1), 33-53. doi: $10.1080 / 14724040308668132$

Ife, J., \& Toseriero, F. (2006). Alternatif pengembangan masyarakat di era globalisasi. Yogyakarta: Pustaka Pelajar. 
Kartasasmita, G. (1996). Pembangunan untuk rakyat-memadukan pertumbuhan dan pemerataan. Jakarta: Pustaka CIDESINDO.

Kementerian Pariwisata. (2015). Rencana strategis pengembangan destinasi dan industri pariwisata kementerian pariwisata tahun 2015-2019. Jakarta: Kementerian Pariwisata.

Kementerian Pariwisata dan Ekonomi Kreatif [Kemenparekraf]. (2020, Februari 10). Data kunjungan wisatawan mancanegara bulanan tahun 2019. Diakses dari https:// www.kemenparekraf.go.id/post/datakunjungan-wisatawan-mancanegarabulanan-tahun-2019

Midgley, J. (1995). Social development: the development perspective in social welfare. California: Sage Publication.

Mikkelsen, B. (2005). Metode penelitian partisipatoris dan upaya-upaya pemberdayaan: sebuah buku pegangan bagi para praktisi lapangan. Jakarta: Yayasan Obor Indonesia.

Moeljarto, V. (1996). Pemberdayaan kelompok miskin melalui IDT dalam Onny S Priyono \& AMW Pranarka (ed.), Pemberdayaan Konsep, Kebijakan dan Implementasi. Jakarta: CSIS.

Häusler, N. (2005). Planning for communitybased tourism: A complex \& challenging task. Dalam Community-based tourism: Between self-determination and market realities: Tourism Forum International at the Reisepavillon. Hannover: The International Ecosystem Society (TIES, Germany). Diakses dari http://www. giz. de/Themen/ de/dokumente/en-tourism-mat

Rianto. (2020). Program Desa Wisata Jogoboyo Purworejo/Pewawancara: Yohanes Putut Wibhisana, Universitas Indonesia, Depok.

Sudjatmiko, T. (2020, Januari 5). Target PAD pariwisata Purworejo terlampaui. krjogja. com. Diakses dari https://www.krjogja. com/berita-lokal/jateng/kedu/target-padpariwisata-purworejo-terlampaui/

Surati. (2020). Program Desa Wisata Jogoboyo Purworejo/Pewawancara: Yohanes Putut Wibhisana, Universitas Indonesia, Depok.
Woro. (2020). Program Desa Wisata Jogoboyo Purworejo/Pewawancara: Yohanes Putut Wibhisana, Universitas Indonesia, Depok. 